\title{
Analisis Akad Pembiayaan Qardh Dalam Lembaga Keuangan Mikro Syariah Daerah Istimewa Yogyakarta
}

\author{
Muhammad Ash-Shiddiqy \\ Universitas Islam Negeri (UIN) Sunan Kalijaga Yogyakarta \\ dickymuhammad1995@gmail.com
}

\begin{abstract}
Abstrak
This study aims to find out how the implementation of the qardh contract in the Almuna Sharia Microfinance Institutions Blessing Mandiri Special Region of Yogyakarta. This study uses an empirical juridical method. Empirical juridical research is used to analyze various regulations regarding qardh financing contracts in Islamic Microfinance Institutions (LKMS) and to analyze applicable laws of community behavior in their lives. The type of data and materials of this study come from primary data and secondary data. Primary data comes from the results of interviews and secondary data derived from literature. The collection technique in this study was conducted by interviewing respondents to get the right and reliable information. The analysis technique used in this research is descriptive method with a qualitative approach.This study found findings, namely financing products carried out at LKMS Almuna Mandiri Blessings, among others, namely Qardh (borrowing virtue). The qardh contract implemented at LKMS Almuna Berkah Mandiri is in accordance with sharia principles. This qardh agreement is intended for LKMS Almuna Berkah Mandiri customers who have small businesses but are not economically capable and want to expand their business. The LKMS Almuna Berkah Mandiri program fund comes from LAZNAS BSM Umat. The amount of qardh financing granted by LKMS Almuna Berkah Mandiri is Rp. 1,000,000.00 (one million rupiah) with a period of 50 (fifty) weeks or equivalent to 1 (one) year over 2 (two) weeks. The qardh installment payment is made after 1 (one) week after the disbursement of funds.
\end{abstract}

\section{Keywords: Funding Agreement, Qardh, Financial Institutions, Sharia}

\section{PENDAHULUAN}

Perkembangan praktik Lembaga Keuangan Syariah (LKS) baik di level nasional maupun internasional telah memberikan gambaran bahwa sistem ekonomi Islam dapat beradaptasi dengan perekonomian konvensional yang telah lama menguasai kehidupan masyarakat dunia maupun di Indonesia. Dengan perkembangan tumbuh dan berkembangnya LKS dapat membuktikan bahwa masyarakat menganggap penting bertransaksi dengan prinsip syariah.

Pesantren sebagai lembaga yang sangat potensial di masyarakat untuk menjadi lembaga pemberdayaan, selain menjadi lembaga pendidikan umat islam dalam 
Vol.5 / No.1: 14-23, Januari 2019,

ISSN : 2599-3348 (online)

ISSN : 2460-0083 (cetak)

peningkatan usaha masyarakat baik secara individu maupun secara kelompok. Hal ini dimaksudan untuk mencapai sumber daya yang optimum, sehingga menunjukkan bahwa kehadiran pesantren benar-benar memberikan berkah terhadap masyarakat sekitar.

Saat ini, Produk Pembiayaan yang dilaksanakan pada LKMS Almuna Berkah Daerah Istimewa Yogyakara meliputi: Murabahah (jual beli barang jadi bayar tangguh), Mudharabah (bagi hasil tanpa sharing dana nasabah), dan Qardh (pinjam kebajikan).

Qardh sebagai salah satu bentuk pembiayaan pada LKMS Almuna berkah DIY secara umum diartikan sebagai kegiatan meminjamkan tanpa adanya imbalan apapun. Dibandingkan dengan sistem LKM konvensional, di mana dalam setiap transaksinya dikenakan bunga atau imbalan yang besarnya telah ditetapkan di muka, maka sistem pembiayaan qardh yang kepada peminjam tidak dikenakan bunga, bahkan peminjam tidak diwajibkan untuk memberikan jaminan, hanya mengembalikan pinjaman.

Dengan adanya pengembangan usaha mikro kecil berupa bertambahnya modal ataupun bertambahnya jenis usaha, maka akan berdampak terhadap bertambahnya tingkat penghasilan dan pendapatan, yang secara langsung akan menekan angka kemiskinan, menekan angka pengangguran.

Beberapa konsep dan prinsip pelaksanaan yang diterapkan pada bidang ekonomi khususnya lembaga keuangan tentunya harus mengacu dan sesuai dengan aturan yang telah ditentukan oleh ketentuan muamalah. Sehingga penerapan muamalah tidak terjadi penyelewengan didalam pelaksanaan akad pembiayaan dalam suatu lembaga keuangan.

Berdasarkan hal tersebut di atas, penulis tertarik untuk meneliti tentang Pelaksanaan Akad Pembiayaan Qardh dalam Lembaga Keuangan Mikro Syariah Daerah Istimewa Yogyakarta.

\section{KAJIAN TEORI}

\section{a. Pengertian Akad}

Istilah yang berkaitan dengan akad dalam Al-Qur'an terdapat dua istilah, yaitu kata akad (al-'aqadu) dan kata 'ahd (al-'ahdu). Kata al-aqadu dalam surat AlMaidah ayat 1 diartikan perikatan atau perjanjian. Sedangka kata al-'ahdu dalam surat An-Nahl ayat 91 dan Al-Isra' ayat 34 berarti masa, pesan, penyempurnaan dan janji atau perjanjian.

Pengertian akad juga terdapat dalam Pasal 20 Peraturan Mahkamah Agung Republik Indonesia Nomor 02 Tahun 2008 tentang Kompilasi Hukum Ekonomi Syariah (KHES). Menurut KHES, akad adalah kesepakatan antara dua pihak atau lebih dalam melakukan perbuatan hukum tertentu.

Secara Etimologi, akad merupakan ikatan antara dua perkara, baik ikatan secara nyata maupun ikatan secara maknawi, dari satu segi maupun dua segi. Pengertian 
Vol.5 / No.1: 14-23, Januari 2019,

ISSN : 2599-3348 (online)

ISSN : 2460-0083 (cetak)

akad dalam arti khusus adalah perikatan yang ditetapkan dengan ijab qabul berdasarkan ketentuan syara' yang berdampak pada objeknya.

Menurut Syamsul Anwar akad adalah pertemuan ijab dan qabul sebagai pernyataan kehendak dua pihak atau lebih untuk melahirkan suatu akibat hukum pada objeknya. Akad transaksi dalam fiqih didenifisikan dengan pertalian ijab dan qabul menurut cara-cara yang disyariatkan yang berpengaruh terhadap objeknya. Ijab adalah permulaan penjelasan yang keluar dari salah satu pihak yang berakad sebagai gambaran kehendaknya dalam mengadakan akad. Qabul yaitu perkataan yang keluar dari pihak berakad pula, yang diucapkan setelah adanya akad.

\section{b. $Q A R D H$}

Secara Etimologi qardh merupakan bentuk masdar yang berarti memutuskan. Menurut Muhammad Syafi'i Antonio qardh adalah pemberian harta kepada orang lain yang dapat ditagih atau diminta kembali atau dengan kata lain meminjamkan tanpa mengharapkan imbalan.

Qardh menurut penjelasan Pasal 19 Huruf e UU No. 2 Tahun 2008 adalah akad pinjaman dana kepada nasabah dengan ketentuan bahwa nasabah wajib menembalikan dana yang diterimanya pada waktu yang telah disepakati. Sedangkan qardh menurut fatwa MUI adalah pinjaman yang diberikan kepada nasabah (muqridh) yang memerlukan. Nasabah qardh wajib mengembalikan jumlah pokok yang diterima pada waktu yang telah disepakati bersama.

Sebagaimana ketentuan dalam Pasal 1 angka 11 Peraturan Bank Indonesia Nomor 7/46/PBI/2005 tentang Akad Penghimpunan dan Penyaluran Dana Bagi Bank yang Melaksanakan Kegiatan Usaha Berdasarkan Prinsip Syariah, Qardh diartikan sebagai pinjam meminjam dana tanpa imbalan dengan kewajiban pihak peminjam mengembalikan pokok pinjaman secara sekaligus atau cicilan dalam jangka waktu tertentu.

Adapun menurut Santoso, karakteristik pembiayaan qardh diantaranya adalah:

1. Tidaklah diperkenankan mengambil keuntungan apapun bagi yang meminjamkan dalam pembiayaan qardh, karena hal tersebut sama dengan riba.

2. Pembiayaan qardh menggunakan akad pinjam-meminjam, ketika barang atau uang telah diterima oleh peminjam maka barang atau uang yang dipinjam berada dalam tanggung jawabnya dengan kewajiban untuk menggembalikan sama dengan pada saat meminjam.

a. Qardh biasanya dalam batas waktu tertentu, namun jika tempo pembayaran diberikan maka akan lebih baik, karena lebih memudahkan bagi peminjam.

b. Jika dalam bentuk uang maka nominal penembalian harus sama dengan nominal pinjaman.

Q ardh yaitu meminjamkan sesuatu kepada orang lain, dimana pihak yang dipinjami sebenarnya tidak ada kewajiban mengembalikan. Melalui qardh maka dapat membantu orang yang berutang di jalan Allah untuk mengembalikan utangnya kepada orang lain tanpa adanya kewajiban baginya untuk mengembalikan utang tersebut kepada pihak yang meminjamkan keberadaan akad ini merupakan 
Vol.5 / No.1: 14-23, Januari 2019,

ISSN : 2599-3348 (online)

ISSN : 2460-0083 (cetak)

karakteristik dari kegiatan usaha LKMS yang berdasarkan pada prinsip tolong menolong.

\section{c. Lembaga Keuangan Mikro Syariah (Lkms)}

Di Indonesia Lembaga Keuangan Mikro (LKM) diatur dalam UU Nomor 13 Tahun 2013 tentang Lembaga Keuangan Mikro. Dalam Pasal 1 disebutkan yang dimaksud dengan LKM adalah lembaga keuangan yang khusus didirikan untuk memberikan jasa pengembangan usaha dan pemberdayaan masyarakat, baik melalui pinjaman atau pembiayaan dalam usaha skala mikro kepada anggota dan masyarakat, pengelolaan simpanan, maupun pemberian jasa konsltasi pengembangan usaha yang tidak semata-mata mencari keuntungan.

Lembaga Keuangan Mikro (LKM) atau Micro Finance Institution (MFI) merupakan lembaga yang melakukan kegiatan penyediaan jasa keuangan kepada pengusaha kecil dan mikro serta masyarakat berpenghasilan rendah yang tidak terlayani oleh Lembaga Keuangan formal dan yang telah berorientasi pasar untuk tujuan bisnis.

Keuangan mikro sendiri adalah kegiatan sektor keuangan berupa penghimpunan dana dan pemberian pinjaman atau pembiayaan dalam skala mikro dengan suatu prosedur yang sederhana kepada masyarakat miskin dan/atau berpenghasilan rendah. Secara internasional istilah pembiayaan mikro atau microfinance sendiri mengacu pada jasa keuangan yang diberikan kepada pengusaha kecil atau bisnis kecil, yang biasanya tidak mempunyai akses perbankan terkait tingginya biaya transaksi yang dikenakan oleh institusi perbankan.

Selain menjalankan aktivitas secara konvensional, LKM juga bisa beroperasi berdasarkan prinsip syariah. Khusus untuk LKMS, kegiatan yang dilakukan dalam bentuk pembiayaan, bukan simpanan. Dalam Pasal 1 ayat (4), UU LKM Pembiayaan disini diartikan sebagai penyedia dana kepada masyarakat yang harus dikembalikan sesuai dengan yang diperjanjikan menurut prinsi syariah. Tujuan adanya LKM adalah:

a. Meningkatkan akses pendanaan skala mikro bagi masyarakat

b. Membantu peningkatan pemberdayaan ekonomi dan produktifitas masyarakat

c. Membantu peningkatan pendapatan dan kesejahteraan masyarakat terutama masyarakat miskin atau berpenghasilan rendah.

Pengertian LKMS yaitu lembaga yang khusus didirikan untuk memberikan jasa pengembangan usaha dan pemberdayaan masyarakat, baik melalui pinjaman atau pembiayaan alam usaha skala mikro kepada anggota masyarakat, pengelolaan simpanan, maupun pemberian jasa konsultasi pengembangan usaha yang tidak semata-mata mencari keuntungan yang dalam operasionalnya menerapkan prinsip syariah. Untuk bisa menjalankan kegiatan usaha, LKMS harus mendapatkan izin dari Otoritas Jasa Keuangan (OJK).

LKMS didefinisikan sebagai lembaga keuangan yang kegiatannya menghimpun dan menyalurkan dana masyarakat yang bersifat profit atau lembaga 
Vol.5 / No.1: 14-23, Januari 2019,

ISSN : 2599-3348 (online)

ISSN : 2460-0083 (cetak)

keuangan syariah nonperbankan yang bersifat informal. Disebut informal karena lembaga ini didirikan oleh masyarakat, berbeda dengan lembaga kuangan perbankan dan lembaga keuangan lainnya.

Lembaga keuangan syariah adalah lembaga keuangan yang melakukan kegiatan usaha berdasarkan prinsip syariah. Kegiatan lembaga keuangan syariah merupakan implementasi dari prinsip ekonomi Islam dengan ciri-ciri yang menonjol, yaitu pelarangan riba dalam berbagai bentuknya, tidak mengenal konsep time-value of money, serta konsep uang sebagai alat tukar, bukan sebagai komoditi yang diperdagangkan.

\section{METODE PENELITIAN}

Dalam penelitian ini menggunakan pendekatan yuridis empiris, sumber data yang digunakan yaitu data primer dan bahan data sekunder. Teknik pengumpulan dalam penelitian ini dilakukan dengan wawancara terhadap responden untuk mendapatkan informasi yang tepat dan terpercaya. Data sekunder adalah data yang diperoleh dengan cara penelitian kepustakaan (library research) yaitu penelaahan terhadap berbagai literature atau bahan pustaka yang berkaitan dengan masalah atau materi penelitian.

Adapun lokasi dalam penelitian ini adalah LKMS Almuna Berkah Mandiri di Jl. KH Ali Maksum Tromol Pos 5, Panggungharjo, Sewon, Bantul, Daerah Istimewa Yogyakarta 55188. Teknik pengambilan sampel pada penelitian ini adalah Non Random Sampling, dengan jumlah sampel dalam populasi kecil serta sampel dalam penelitian ini telah ditentukan. Non Random Sampling merupakan suatu cara menentukan sampel dimana peneliti telah menentukan atau menunjuk sendiri sampel dalam peneliannya. Populasi dalam penelitian ini adalah semua yang memiliki hubungan dengan pembuatan akad pembiayaan qardh dalam LKMS Almuna Berkah Mandiri, yang terdiri dari pengurus LKMS Almuna Berkah Mandiri dan peminjam melalui akad pembiayaan qardh di LKMS Almuna Berkah Mandiri.

\section{HASIL PENELITIAN}

\section{a. PELAKSANAAN AKAD QARDH DI LKMS ALMUNA BERKAH MANDIRI}

Pelaksanaan akad qardh di LKMS Almuna Berkah Mandiri telah sesuai dengan prinsip syariah. Pembiayaan qardh dalam LKMS merupakan pembiayan yang tanpa adanya margin dan bagi hasil antara nasabah dan LKMS. Pelaksanaan akad qardh di LKMS Almuna Berkah Mandiri ini legal dan diawasi langsung oleh Otoritas Jasa Keuangan (OJK) serta terdaftar Dinas Koperasi Daerah.

Pembiayaan qardh merupakan pembiayaan yang diberikan kepada yang tidak mampu atau dalam kesusahan untuk membiayai usahanya yang dinilai produktif dimana anggota tidak dituntut atas bagi hasil maupun margin keuntungan, tetapi mengembalikan pokoknya saja sebesar dana yang dipinjamkan. Dalam melakukan 
Vol.5 / No.1: 14-23, Januari 2019,

ISSN : 2599-3348 (online)

ISSN : 2460-0083 (cetak)

pembiayaan qardh rukun yang dipenuhi yaitu: peminjam (muqtaridh), pemberi pinjaman (muqridh), pinjaman (qardh) dan ijab qabul (sighat).

Dana program LKMS Almuna Berkah Mandiri ini bersumber dari (Lembaga Amil Zakat Nasional Bina Sejahtera Masyarakat) LAZNAS BSM Umat. Status dana program ini merupakan hibah bertujuan khusus (Muqayyadah) yang dikhususkan untuk persiapan kelembagaan dan operasional LKMS dalam mengelola perguliran modal ke masyarakat miskin melalui Kelompok Usaha Masyarakat Sekitar Pesantren Indonesia (KUMPI).

Tidak semua orang dapat memperoleh qardh pada LKMS almuna berkah mandiri, namun penerima pembiayaan terbatas pada nasabah yang memiliki usaha kecil yang kurang mampu secara ekonomi, kurang memiliki pengetahuan tentang bisnis namun ingin mengembangkan usahanya. Sasaran program masyarakat mikro sekitar pondok pesantren adalah masyarakat mikro yang potensial produktif yang memiliki kemauan dan semangat untuk bekerja, bagian masyarakat miskin yang amanah dan dapat dididik, dan memenuhi indeks kelayakan anggota. Untuk area cakupan wilayahnya adalah kurang lebih $5 \mathrm{KM}$ dari Pondok Pesantren Al-Munawwir Krapyak atau Kecamatan Sewon.

Sasaran lingkungan pondok pesantren yaitu santri, alumni, keluarga santri dan keluarga pengasuh yang masih bertempat tinggal disekitar pondok pesantren (mukim) yang memiliki usaha produktif dan bekomitmen serta harus mengikuti prosedur KUMPI, dengan maksimal pembiayaan untuk sasaran ini adalah $30 \%$ dari total portofolio pembiayaan LKMS. Dalam menyalurkan dananya LKMS tidak begitu saja dengan mudah memberikan pinjaman kepada nasabah. LKMS tetap menggunakan prosedur analisis pembiayaan. Analisis pembiayaan di LKMS menggunakan prinsip 5C, untuk meminimalkan risiko bermasalahnya atau tidak kembalinya Pembiayaan. Kelima prinsip 5C tersebut meliputi:

Pertama, Caracter (watak dan kepribadian nasabah). Merupakan keyakinan pihak LKMS bahwa si peminjam mempunyai moral, watak, ataupun sifat-sifat pribadi yang positif dan koperatif dan juga mempunyai rasa tanggung jawab baik dari kehidupan pribadi sebagai manusia, kehidupan sebagai anggota masyarakat ataupun dalam menjalankan kegiatan usahanya. Kedua, Capacity (kemampuan nasabah). Merupakan suatu penilaian kepada calon nasabah mengenai kemampuan melunasi kewajiban-kewajibannya dari kegiatan usaha yang dilakukannya atau kegiatan usaha yang akan dilakukannya yang akan dibiayai dengan pembiayaan dari LKMS. Jadi jelaslah maksud dari penilaian terhadap capacity ini untuk menilai sampai dimana hasil usaha yang akan diperolehnya tersebut, akan mampu untuk melunasinya tepat waktu sesuai dengan perjanjian yang telah disepakatinya. Ketiga, Capital (modal dari nasabah). Merupakan penilaian terhadap jumlah dana atau modal sendiri yang dimiliki oleh nasabah. Yang meliputi aset usaha, tanah, dan tabungan. Keempat, Colateral (jaminan pembiayaan). Dilakukan suatu penilaian terhadap barang-barang jaminan yang diserahkan oleh peminjam atau debitur sebagai jaminan atas pembiayaan yang diterimanya. Kelima, Condition (keadaan 
Vol.5 / No.1: 14-23, Januari 2019,

ISSN : 2599-3348 (online)

ISSN : 2460-0083 (cetak)

ekonomi lingkungan usaha). Penilaian terhadap situasi dan kondisi politik, sosial, ekonomi, budaya, dan lain-lain yang mempengaruhi kondisi perekonomian pada suatu saat.

Setelah pembiayaan dikabulkan, maka LKMS akan melakukan pendampingan kepada nasabah. Pendampingan dilakukan setiap minggu ketika HALMI (Halaqah Mingguan) dilakukan. Pendampingan yang dilakukan mengenai pengembangan usaha, manajemen ekonomi rumah tangga disertai pendidikan agama. Konsultasi pengembangan usaha dilakukan oleh jasa layanan profesional yang dilakukan untuk nasabah yang keilmuan yang mengutamakan adanya olah pikir tentang pengembangan usaha. Pendampingan usaha yang dilakukan menjelaskan mengenai tugas dan proses analisis tentang peluang pertumbuhan potensial, dukungan dan pemantauan pelaksanaan peluang pertumbuhan usaha, tetapi tidak termasuk keputusan tentang strategi dan implementasi dari pertumbuhan usaha.

Jangka waktu pembayaran kembali pinjaman di LKMS ini diangsur pada setiap pertemuan kelompok, 50 kali angsuran dengan dibayarkan setiap minggu pada saat HALMI beserta biaya administrasi yang telah dibebankan kepada anggota. Pembayaran angsuran pinjaman dimulai satu minggu atau tujuh hari sejak uang pinjaman diterima anggota. Misalnya qardh cair pada tanggal 1 januari 2017 maka pada tanggal 8 januari 2017 nasabah wajib mengembalikan qardh. Pembayaran dilakukan ditempat yang telah disepakati oleh anggota kelompok.

Pada setiap pertemuan Rumpun, peminjam (nasabah) akan membayar angsuran mingguan dengan formula sebagai berikut:

$\mathrm{A}=\frac{P+S+T M}{50}$ dimana: $\mathrm{A}=$ Pembayaran setiap minggu, $\mathrm{S}=$ Sadaqah $(2,5 \% \mathrm{x}$ Pinjaman), TM = Total tabungan mingguan (Rp. 1000,- x $50=$ Rp. 50.000,-)

Sebagai contoh, Pinjaman Rp. 1.000.000,- maka angsurannya adalah sebagai berikut:

$$
\begin{aligned}
& A=\frac{1.000 .000+(1.000 .000 \times 2,5 \%)+50.000}{50} \\
& A=\frac{1.000 .000+25.000+50.000}{50} \\
& A=\frac{1.075 .000}{50} \\
& A=\text { Rp. } 21.500,-
\end{aligned}
$$

Angsuran mingguan ini terdiri dari:

$\begin{array}{lll}\text { Pokok pinjaman } & : \frac{1.000 .000}{50} & =\text { Rp. 20.000,- } \\ \text { Biaya administrasi } & : \frac{1.000 .000 \times 2,5 \%}{50} & =\text { Rp. 500,- } \\ \text { Tabungan mingguan } & : \frac{25.000}{50} & =\text { Rp. 1000,- }\end{array}$

Jumlah angsuran setiap minggu : Rp. 21.500,- 
Vol.5 / No.1: 14-23, Januari 2019,

ISSN : 2599-3348 (online)

ISSN : 2460-0083 (cetak)

Pokok pinjaman adalah dana yang diberikan kepada nasabah yang wajib dikembalikan sesuai jumlah pokok yang dipinjamkan. Tabungan mingguan merupakan tabungan yang dikumpulkan setiap minggunya ketika HALMI. Tabungannya sebesar Rp. 1000,- per nasabah Pada akhir pengembalian, dan ketika sudah akan lunas maka tabungan dapat diambil kembali. Tabungan disimpan/dititipkan pada lembaga dan admisintrasinya ada pada buku tabungan anggota.

Dan apabila pada saat HALMI kelompok mingguan terdapat anggota yang tidak hadir karena berhalangan, misalkan sakit, maka anggota lain dalam satu kelompok bertanggung jawab membayar angsuran mingguannya. Karena mekanisme yang diterapkan dalam pembiayaan akad qardh adalah sistem tanggung reteng. Pembiayaan sistem tanggung renteng berlaku selama dua angsuran pengembalian. Jika lebih dari dua kali maka tidak dapat menggunakan sistem tanggung renteng yang menggunakan tabungan kelompok nasabah.

Alur pembayaran angsuran di LKMS Almuna Berkah Mandiri yatu dengan cara membayar angsuran yang dilakukan melalui ketua kelompok, pada saat Halaqah Mingguan ketua kelompok akan menyerahkan kepada petugas lapang LKMS. Pembayaran ansuran dilakukan di rumah nasabah secara bergilir atau atas kesepakatan anggota kelompok dan petugas LKMS Almuna Berkah Mandiri.

Jika nasabah telat melakukan angsuran pembayaran 1 kali pembayaran, maka LKMS akan mengingatkan nasabah melalui ketua kelompok. Jika telat pembayaran 2 (dua) kali akan diingatkan melalui ketua KUMPI. Jika 3 kali tidak melakukan angsuran maka akan ditangani oleh supervisor dengan didatangi kerumah, dan diberi surat peringatan. Apabila salah nasabah tidak melakukan angsuran pada minggu keempat, maka petugas LKMS akan mendatangi rumah nasabah dan akan diminta penjelasan gimana kelanjuta pembayarannya. Jika nasabah tidak mau melanjutkan pembiayaan, maka wajib menggembalikan uang yang telah diberikan oleh LKMS Almuna Berkah Mandiri untuk nasabah sejumlah dana yang belum dikembalikan, dan mencari pengantinya untuk memenuhi kelompok yang akan kosong jika nasabah itu keluar dari pembiayaan qardh.

Ketika akan lunas maka nasabah diperkenankan untuk melakukan pengajuan pembiayaan baru, supervisor LKMS akan melakukan uji prestasi untuk melihat langsung usaha yang dijalankan selama menjadi nasabah KUMPI. Dalam uji prestasi ini juga disusun rencana usaha (rencana pengajuan pembiayaan) sebagaimana proses awal pembiayaan. Dan dapat mengikuti alur siklus perguliran pencairan pembiayaan dan seterusnya.

Sejak bulan agustus 2017, nasabah yang mendaftar untuk mengajukan pembiayaan qardh di LKMS yaitu sebanyak 205 nasabah, yang terbagi dalam 5 Rumpun atau 40 KUMPI. Dan yang mengajukan pembiayaan terdiri dari mayoritas masyarakat sekitar pesantren dan santri yang akan membuka usaha sendiri. 
Vol.5 / No.1: 14-23, Januari 2019,

ISSN : 2599-3348 (online)

ISSN : 2460-0083 (cetak)

\section{KESIMPULAN}

Dari pembahasan di atas dapat disimpulkan bahwa:

1. Pelaksanaan pembiayaan qardh dalam LKMS Almuna Berkah Mandiri Daerah Istimewa Yogyakarta adalah sebagai berikut:

a. Pelaksanaan pembiayaan qardh dalam LKMS Almuna Berkah Mandiri Daerah Istimewa Yogyakarta telah sesuai dengan prinsip syariah.

b. Akad qardh ditujukan untuk nasabah LKMS Almuna Berkah Mandiri yang memiliki usaha kecil namun tidak mampu secara ekonomi dan ingin mengembangkan usahanya.

c. Dana program LKMS Almuna Berkah Mandiri ini bersumber dari LAZNAS BSM Umat. Status dana program ini merupakan hibah bertujuan khusus (Muqayyadah) yang dikhususkan untuk persiapan kelembagaan dan operasional LKMS dalam mengelola perguliran modal ke masyarakat miskin melalui Kelompok Usaha Masyarakat Sekitar Kepesantren Indonesia (KUMPI).

d. Alur pembiayaan di LKMS Almuna Berkah Mandiri yaitu: Identifikasi, Sosialisasi, Uji Kelayakan, Pra-PWK (Pelatihan Wajib Kelompok), dan PWK. Setelah pencairan maka diadakan HALMI (Halaqah Mingguan) yang dilakukan di rumah nasabah atau kesepakatan bersama antara nasabah dan petugas LKMS Almuna Berkah Mandiri.

e. Besarnya pembiayaan qardh yang dikabulkan oleh LKMS Almuna Berkah Mandiri yaitu sejumlah Rp. 1.000.000,00- (satu juta rupiah) dengan jangka waktu 50 (lima puluh) minggu atau setara dengan 1 (satu) tahun lebih 2 (dua) minggu.

f. Tidak ada jaminan yang diajukan oleh LKMS Almuna Berkah Mandiri terhadap nasabah pembiayaan akad qardh.

g. Akad qardh di LKMS Almuna Berkah Mandiri telah ditentukan, yaitu memuat: data anggota dan keluarga, indeks rumah tinggal, pendapatan, kepemilikan asset, pernyataan pernah/sedang berhutang, dan kebutuhan pinjaman.

h. Qardh dapat dicairkan kepada nasabah setelah petugas LKMS Almuna Berkah Mandiri melakukan penelitian uji kelayakan kepada nasabah. Cara penilaian kelayakan anggota ada 4 kriteria, yaitu Indeks Rumah (IR), Indeks Pendapatan (IP), Indeks Asset (IA) dan Indeks Kepemilikan Tanah (IAT).

i. Pembayaran angsuran qardh diserahkan kepada ketua kelompok pada saat Halaqah Mingguan, kemudian ketua kelompok akan menyerahkan kepada petugas LKMS Almuna Berkah Mandiri.

j. Pembayaran angsuran qardh dilakukan setelah 1 (satu) minggu setelah pencairan dana.

2. Upaya LKMS Almuna Berkah Mandiri agar nasabah mengembalikan pinjaman adalah dengan cara mengadakan Halaqah mingguan (HALMI). Jika terjadi 
Vol.5 / No.1: 14-23, Januari 2019,

ISSN : 2599-3348 (online)

ISSN : 2460-0083 (cetak)

wanprestasi maka akan dilakukan dengan cara mediasi, mendatangkan mediator, melalui Badan Arbirase Nasional atau melalui pengadilan agama.

\section{DAFTAR PUSTAKA}

Abdul Ghafur Anshori. (2007). Perbankan Syariah Di Indonesia, yogyakarta: Gadjah Mada University Press.

Ahmadi Miru. (2012). Hukum Kontrak Bernuansa Islam, Jakarta: PT Raja Grafindo Persada.

Dwi Suwiknyo. (2010). Kompilasi Tafsir Ayat-Ayat Ekonomi Islam Buku Referensi Rogram Sudi Ekonomi Islam, Yogyakarta: Pustaka Pelajar

Dian Pratomo, dkk. (2009). "strategi lembaga keuangan mikro syariah dalam mengembangan usaha mikro", Jurnal MPI, IV

I Gde Kajeng Baskara, “Lembaga Keuangan Mikro Di Indonesia”, Buletin Studi Islam, XVII (Agustus, 2013).

Jenita. (2017). "Peran Lembaga Keuangan Mikro Dalam Pemberdayaan Ekonomi Masyarakar Kecil Menengah", Al Masraf, II.

Muhammad Syafi'i Antonio. (2001). Bank Syariah : Dari Teori Ke Praktik, Jakarta: Gema Insani Press.

Ninik Sri Rahayu. (2015). “Kontribusi Lembaga Keuangan Mikro Syariah Dalam Pemberdayaan Perempuan”, Jurnal Inovasi Kewirausahaan, II. 